\title{
Investments in green economy as a driving force for sustainable economic development
}

\author{
Aleksey Mikryukov*, Tatyana Chilimova, and Anna Serebrennikova \\ Ural State University of Economics, 8 Marta st./ Narodnoj Voli st. 66/45, 620144 Yekaterinburg, \\ Russia
}

\begin{abstract}
The paper is devoted to the study of investments in green energy as a driving force for sustainable economic development. The paper highlights the features of sustainable economic development, the relationship between economic development and environment, the goals in the field of sustainable development and current trends in their implementation. The key directions of sustainable economy are identified on the basis of a combination of productive elements of foreign practice and domestic experience available in this area. The theoretical aspects of the concept of "green economy" and its tasks at the present stage are considered. Energy remains the key element in clean technologies. A definition of green investments is given by the authors. Green investments solve the problems of increasing energy efficiency, accelerating the development of renewable energy sources from alternative sources leading to the improved environment. The paper presents the dynamics of investments in green technologies in the Russian Federation and abroad, a brief analysis of the goals and direction of projects in the context of economic and social impact given. The authors conclude that the development of financial instruments and investment instruments is interdependent with the development of green economy and the sustainability of economy.
\end{abstract}

\section{Introduction}

Currently, investments in green energy are becoming more and more popular and relevant as the entire world community faces the task of improving environmental situation as well as strengthening sustainable development and forming "green economy". Green economy is the so-called economic sector, which embodies ecological values of modern society. Along with digitalization, one of the global trends is transition to green energy based on the principles of combining the interests of society and preserving nature. The need to introduce "green energy" or energy production based on renewable energy sources (RES) has become one of the postulates of global energy policy. According to expert estimates, by 2030 , about $\$ 93$ trillion is planned to be allocated for "green" energy projects [28], which will require a widespread use of appropriate financial instruments. In this regard, the tasks of forming the Russian system of "green" financing of renewable energy sources are being

\footnotetext{
* Corresponding author: fbd-mav@yandex.ru
} 
updated, which will give us a chance to verify projects based on the national taxonomy and attract funding from both Russian and international investors.

\section{Materials and Methods}

The scientific basis for theoretical and applied research conducted in this area is the methodology of systematic analysis of the problems of greening public policy, considered from the point of view of determining the possibilities of accelerating transition to sustainable development and formation of green economy; reports of commercial banks, reports of the World Economic Forum on "green" financing of renewable energy projects. The main provisions of structural and situational analysis using the methods of synthesis, deduction, and induction are applied.

\section{Results and Discussion}

In the modern world, dynamic global changes are taking place in all spheres of people's lives. Therefore the most foreground task of the entire society is to ensure sustainable development of the economy. The past decades have been marked with numerous achievements in the field of sustainable economic development, especially in advanced economies, but many developing countries have also recognized the need to achieve sustainable economic development in all areas. The current economic model of human development is unstable, in other words, it creates high risks for the further development of future generations, since only economic aspects are taken into account whereas social and environmental ones are often ignored.

At the end of the last century, in the 1970s and 1980s, the problems of the development of society, science, limited natural resources and environmental degradation became more obvious and recognized by mankind. In that time there appeared the concept of sustainable development. In the report of the UN Commission on Environment and Development "Our Common Future" in 1987, the following wording of the concept was first given: "...sustainable development is such a development when current activities and satisfying the needs of modern society do not do harm to future generations, but there is a balance between them" [18]. Within the framework of this concept, the Millennium Development Goals (MDGs) were adopted in 2001. These goals announced global initiatives aiming at improving life in the world by 2015 , focusing on overcoming hunger, poverty, ensuring access to education and gender equality, and protecting health and environment. To continue realizing the MDGs in 2015, the Sustainable Development Goals (SDGs) shown in Figure 1 were formulated. They are aimed at improving the management of economic, environmental and social aspects of world development, which should be achieved by 2030 $[29,36]$. 

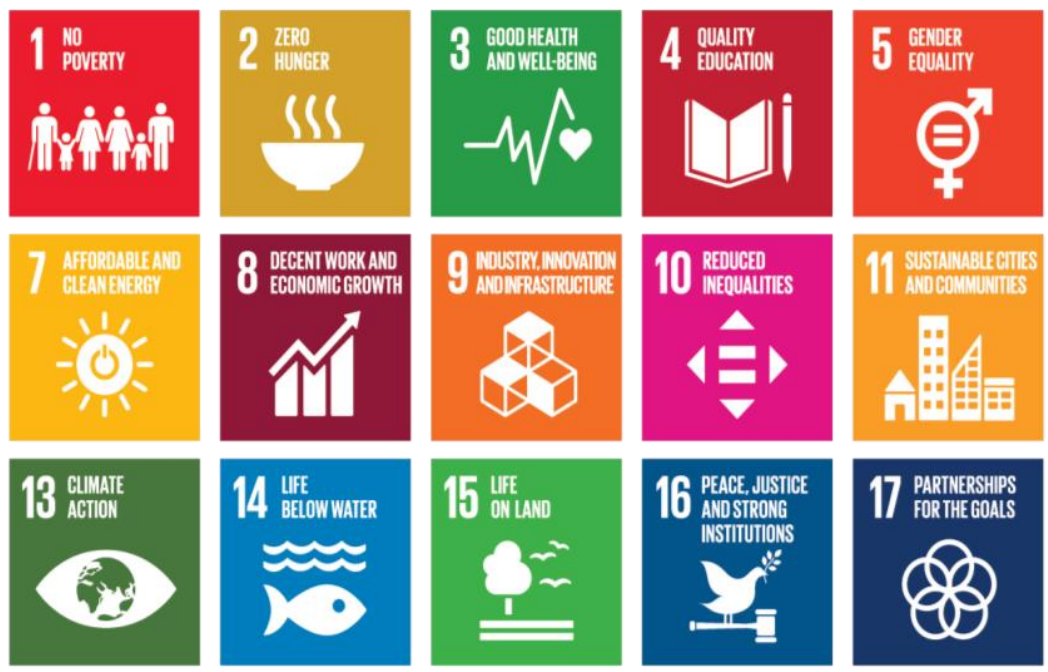
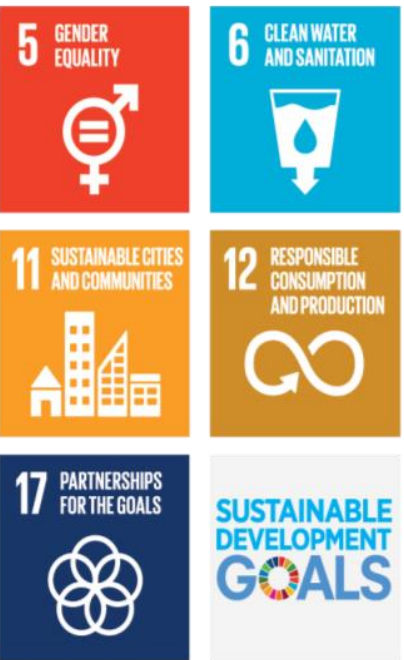

SUSTAINABLE DEVELOPMENT GOALS

Fig. 1. The goals of sustainable development of the system (compiled by the author according to [24])

In science, the term "sustainable economy" refers to: "... the ability to preserve the original state and the rational use of resources in connection with changes or uncertainties in the internal or external environment." At the same time, "sustainable economic development is economic growth that does not do harm to the environment and contributes to solving social problems, finding a balance between economic and environmental development" [18]. These definitions have small contradictions. To eliminate them, there should be a push, which may be an interest in improving the efficiency of economic entities functioning in order to meet economic, social and environmental needs, leading to increased reproduction, transition to new economic processes, and eventually to sustainable economy.

However, in the modern world, sustainable development is often considered as an almost unattainable ideal in the realities of market economy that defines competition as the main engine of its future development, instability usually taken for granted [4, 26]. At the same time, according to experts, it is possible to determine the key directions of sustainable development based on a combination of productive elements of foreign practice and domestic experience available in this area [19]. As for the material basis for transition to sustainable development, it can be provided by the widespread practical implementation of tested models of green and closed economy. It is possible to distinguish three main subsystems in the socio-ecological and economic system as an object of sustainable development of green economy, etc. (Figure 2). 


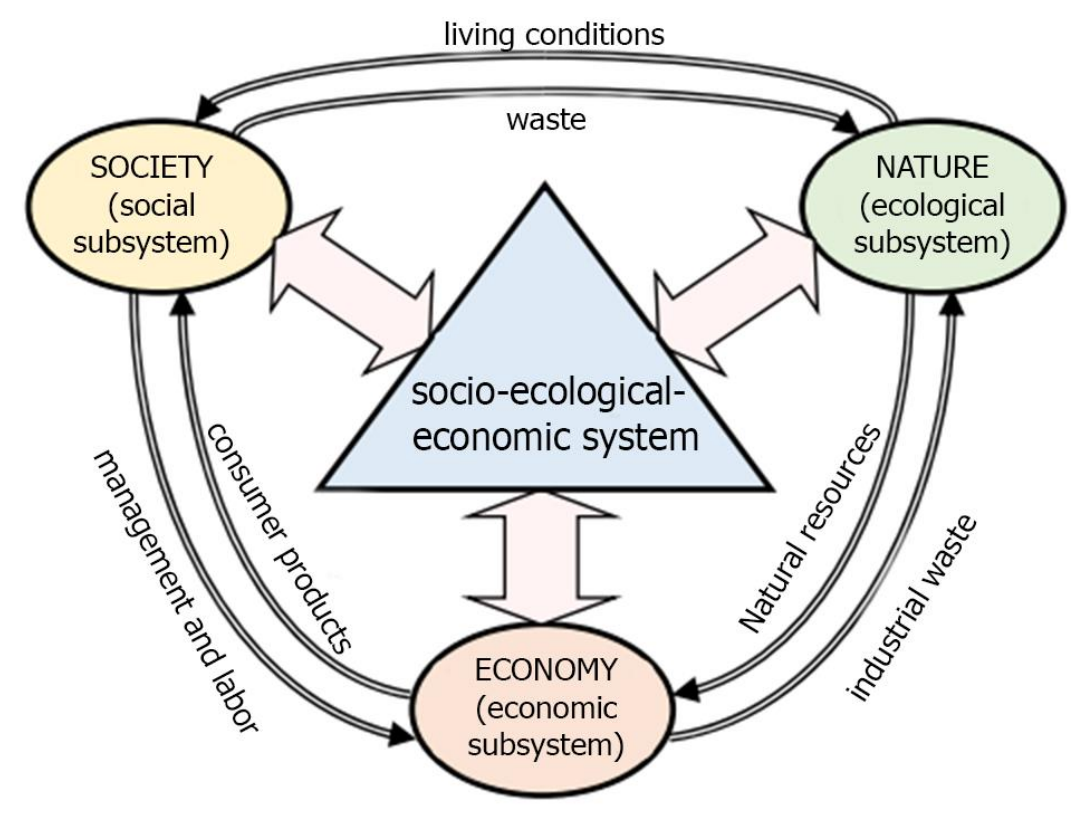

Fig. 2. The interaction of sustainable development components in the socio-ecological and economic system (compiled by the author according to $[19,26]$ )

Currently, the main trends of sustainable development include:

- mitigation of climate change (reduced greenhouse gas emissions, use of renewable energy sources and low-carbon technologies);

- review of the climate changes occurred and assessment of climate risks (extreme weather and climate conditions require a thorough assessment of associated risks, upgrading infrastructure, and additional funding for the necessary changes);

- development of a closed-cycle economy (implementation of cyclical strategies in production and consumption: modernization of goods that require fewer materials and less energy; development of systems for returning products, reuse of waste; replacement of final materials with renewable ones, etc.);

- reducing the use of plastic and replacing it with more environmentally friendly alternatives;

- development of sustainable and conscious consumption (expanding production and increasing the availability of environmentally friendly products);

- use of the latest technologies to solve economic and social problems;

- development of the sustainable and responsible financing market (expanding the offer of investment products that contribute to solving social and environmental problems; financial support for companies implementing energy-saving technologies and realizing sustainable development goals).

The coronavirus pandemic has had a significant impact on the concept of sustainable economic development, "green technologies" increasing. Their use significantly reduces the harmful human impact on the environment and makes business responsible. Investments in "green technologies" occupy the 3rd place in the world after the ones in the information technology and biomedicine sectors. The government is accomplishing various measures to increase the interest of enterprises aiming at increasing profits, in launching green technologies through the introduction of new production standards, and provision of subsidies. Along with improving the quality of the environment, green economy transformations can further increase GDP, create new jobs, create new industries and 
services, reduce resource consumption and increase consumption of by-products, and provide healthier and more equitable living conditions for the population $[3,7]$.

Most of the countries of the world, primarily the EU and the US, are focused on economic recovery based on the principles of responsible financing (ESG) - the world is becoming "greener". According to the EU "Green Deal" program, greenhouse gas emissions in the EU should be completely stopped by 2050 [31]. The transition to renewable energy sources will reduce the demand for Russian energy resources. The expected losses of the Russian economy from the introduction of a carbon tax by the EU countries, according to calculations in 2025-2030, will amount to more than 33 billion euros in the baseline scenario [6].

It should be noted that Russia significantly loses to many countries in the world in the development of "green technologies". Thus, only $1 \%$ of Russian patents for the use of these technologies are present on the world market. However, Russia is interested in increasing the use of "green technologies" and is taking various steps. One of the most significant events was Russia's accession to the Paris Agreement in 2019, which contains a package of measures to reduce the content of carbon dioxide in the atmosphere since carbon monoxide is considered one of the most significant factors leading to climate change. The volume of investment has increased significantly. The largest part of the investments is directed at producing solar energy, introducing energy-saving technologies and equipment, developing and producing electric transport. The potential of introducing green technologies in Russia until 2023 is estimated at 3 trillion rubles. [21]. However, sustainable, and moreover, climate projects are quite expensive and currently unprofitable, but have the prospect of increasing profits in the long term. In this regard, the key task today is the formation of the Russian system of "green investments", which will give us a chance to verify projects based on the national taxonomy and attract finance from both Russian and international investors. In this context, the formation of green economy should be considered as a natural process, interrelated with sustainable development.

For the past few years, the Russian community has been demonstrating its interest in improving the quality of life by increasing responsibility for the environmental situation and the cleanliness of the living environment. Most corporations implement policies to reduce the harmful impact of production on the environment and people's lives. For a better life, citizens of the country strive to improve its quality, comfort, and reduce morbidity. A good example is the growing popularity of eco-products and materials. Eco-activism and eco-volunteerism are developing in the country. Under the influence of the corresponding public demand, business structures are showing interest in eco-projects, at least in the context of image investments. Modern cities are becoming not only smart, but also environmentally friendly. Green business opportunities are emerging, opening up access to new sources of income. New types of businesses are being formed in completely different industries, for example, the production of solar panels, electric transport.

However, the issues of financing development and formation of "green" economy are quite complex. Ideally, green economy should "... bring humanity into a state of balance with nature, in which people will return to nature as much as they have taken from it" [10]. At the same time, green financing means:

- $\quad$... targeted environmental investments providing environmental benefits in the context of socio-economic development of the country" [20];

- “... money, securities, property, including property and other rights invested in the objects of entrepreneurial and (or) other activities carried out for profit, the negative impact on the environment limited, i.e. the effect of decoupling" achieved" [32];

- “... allocating capital for projects the purpose of which is to benefit the environment" [34].

The above definitions have common features: 
- indicating the financing mechanism, i.e. the instrument or financial process or technology, in particular investments, assets (cash, securities, etc.), capital allocation. It should be noted that financial processes and technologies are implemented through various financial instruments;

- specifying the end effect or goal. These include environmental benefits, limiting negative impacts, and environmental benefits.

Based on the above definitions and their generality, the authors consider it possible to formulate a synthetic definition of green investments. Green investments should be understood as financial instruments aimed at attracting capital, as well as financial resources to improve the energy efficiency of companies, to reduce resource consumption and negative environmental impact by optimizing production, increasing profitability and achieving a balance between environment and economy. The instruments include already existing ones, such as: "green" loans, "green" bonds, "green" insurance, state support instruments, as well as newly emerging mechanisms. For example, the first "green" bonds were placed in 2019 when the sustainable development sector appeared on the Moscow Stock Exchange, and in 2020 new emission standards were adopted defining the requirements for these bonds. Within two years, environmental lending more than doubled (from 11 countries in 2019 to 23 in 2020). The USA ranks first (\$ 51.1 billion), Germany second ( $\$ 40.2$ billion), France - third ( $\$ 32.1$ billion), China - fourth ( $\$ 17.2$ billion), the Netherlands - fifth (\$17.0 billion). France was still in the top three in 2017, 2018 and 2019, and Germany was there for the first time. According to the Climate Bonds Initiative, the global green finance market saw a record total issuance of $\$ 269.5$ billion in 2020 , an increase of $\$ 3$ billion compared to the previous year [15].

The main component in "green technologies" is green energy. The vector of its greening is the improvement of energy efficiency and the development of new energy sources. Priority is given to renewable energy sources (RES), which have an inexhaustible resource due to natural phenomena and solar energy.

The main goals of green energy are as follows [7,8]

- reducing pollution and waste generation by changing production and consumption patterns;

- meeting social needs through ways that can continue to be used indefinitely in the future without depleting or damaging natural resources;

- developing and implementing alternative solutions to replace technologies that harm the environment;

- making products that can be reused or regenerated, thus completing the production cycle from start to finish.

- creating a center of economic activity focused on products and technologies useful for the environment, accelerating the speed they can be implemented at.

The first experiments using clean technologies were recorded in the early 1990s. Construction, implementation and operation of green energy facilities were very expensive, so to stimulate this direction, many developed countries introduced various measures of state support (tariff reduction, tax incentives). This has led to impressive results in the field of environmentally friendly electricity production. If in 1998 investments in this industry were about $\$ 10$ billion, then 10 years later they grew to $\$ 100$ billion. In 2020, the volume of investments in renewable energy sources exceeded 280 billion dollars [30]. Table 1 shows the amount of green finance in the global economy, as estimated by a number of specialized news agencies in this sphere. 
Table 1. The volume of green finance in the global economy*

\begin{tabular}{|c|c|c|c|}
\hline Resources & Content & $\begin{array}{l}\text { Annual flows, bln. } \\
\text { of US dollars per } \\
\text { year }\end{array}$ & $\begin{array}{l}\text { Announced cost } \\
\text { of new projects }\end{array}$ \\
\hline UNCTAD & $\begin{array}{l}\text { Low-carbon investments in new projects in } \\
\text { renewable energy, waste recycling, and low-carbon } \\
\text { manufacturing }\end{array}$ & $\begin{array}{c}90-82 / \\
2009-2019\end{array}$ & $\begin{array}{c}955-833 / \\
2009-2019\end{array}$ \\
\hline OECD & $\begin{array}{l}\text { Investments in environmental goods and services, } \\
\text { presented as investments in electricity, gas and } \\
\text { water supply }\end{array}$ & $\begin{array}{c}41 / \\
\text { average annual level } \\
2015-2017\end{array}$ & $\begin{array}{c}748 / \\
\text { average annual } \\
\text { level } \\
2015-2017\end{array}$ \\
\hline $\begin{array}{c}\mathrm{fDi} \\
\text { Intellegenc } \\
\mathrm{e}\end{array}$ & $\begin{array}{l}\text { Investments in renewable energy( new projects in } \\
\text { the field of solar, wind, bio- and hydroelectric } \\
\text { power, geothermal, marine and other renewable } \\
\text { energy) }\end{array}$ & $\begin{array}{c}76 / \\
2019\end{array}$ & $\begin{array}{l}772 / \\
2019\end{array}$ \\
\hline $\begin{array}{l}\text { New } \\
\text { Energy } \\
\text { Finances } \\
\text { Bloomberg }\end{array}$ & $\begin{array}{l}\text { Mergers and acquisitions, new projects in the areas } \\
\text { of renewable energy (biofuels, small hydroelectric } \\
\text { power plants, wind and solar energy), clean energy } \\
\text { services (e.g. carbon markets) and smart energy } \\
\text { technologies (e.g. digital energy, energy efficiency } \\
\text { and energy storage). }\end{array}$ & $\begin{array}{l}287 / \\
2019\end{array}$ & $\begin{array}{l}833 / \\
2019\end{array}$ \\
\hline
\end{tabular}

Compiled by the author based on [33]

According to experts, in 2019-2020, the list of countries leading in the number of green energy projects with participation of direct foreign investors includes the United States, Spain, Egypt, and Vietnam (Table 2).

A number of companies in the alternative energy sector are of particular interest to investors:

- Sunnova Energy International (USA), a leading provider of services for household solar energy and its storage, is engaged in the management of solar storage systems and it is the largest manufacturer of solar panels placed on the roofs of houses. It was founded in 2012 in Houston, Texas, and serves more than 63,000 customers in more than 20 states in the United States. In 2020 the company's revenue increased by $22.2 \%$ compared with the previous year and amounted to $\$ 160$ million. The company's shares in 2020 aroused great interest and almost trebled in price by the end of the year [33];

- Sunrun is a leading national company, founded in 2007. It provides services in the field of solar energy, and energy storage in the residential sector. The company has developed maintenance plans for home solar panels to make local clean energy more accessible to everyone with or without minimal upfront costs. Sunrun has 573,000 customers, selling solar services in 22 states, the District of Columbia, and Puerto Rico. Customer growth amounted to $18 \%$ in 2020. Financial indicators show a rapid growth of the company. Total revenue was $\$ 334.8$ million. The first quarter of 2021 saw an increase of $\$ 124.1$ million, i.e. by $59 \%$ over the first quarter of 2020. Experts predict the company's growth in the coming year by $25-30 \%$. The company's shares are currently being traded at $\$ 44$. In comparison with the previous year, the price has increased almost 3 times from $\$ 14.36$, with forecast for further growth [33];

- $\quad$ - Clearway Energy (USA), founded in 2012, is one of the largest renewable energy owners in the US with more than 4,200 MW of installed wind and solar generation projects. Clearway Energy also owns approximately 2,500 net MW of clean, highefficiency natural gas production facilities, as well as a portfolio of district energy systems. Last year their revenue increased by $13.9 \%$, and reached $\$ 1,199$ million. The shares are traded on the New York Stock Exchange. The company has a goal to ensure the growth of dividends to investors. The shares of Clearway Energy last 
year were traded first at the price of $\$ 14.4$, and reached $\$ 35.8$., showing a growth potential [33];

Table 2. Countries leading in the number of green energy projects with participation of direct foreign direct investors, 2019-2020*

\begin{tabular}{|c|c|c|c|c|c|}
\hline Country & $\begin{array}{c}\text { Number of } \\
\text { projects }\end{array}$ & \multirow[t]{6}{*}{ America } & Country & $\begin{array}{c}\text { Number of } \\
\text { projects }\end{array}$ & \multirow[t]{6}{*}{ Europe } \\
\hline USA & 36 & & Spain & 19 & \\
\hline Mexico & 19 & & France & 11 & \\
\hline Brazil & 12 & & Russia & 10 & \\
\hline Chile & 10 & & Great Britain & 9 & \\
\hline Canada & 3 & & Netherlands & 8 & \\
\hline Vietnam & 23 & \multirow{5}{*}{$\begin{array}{l}\text { Asia-Pacific } \\
\text { region }\end{array}$} & Egypt & 5 & \multirow{5}{*}{$\begin{array}{l}\text { Near East } \\
\text { and Africa }\end{array}$} \\
\hline Australia & 20 & & Iran & 5 & \\
\hline India & 12 & & Morocco & 3 & \\
\hline Japan & 12 & & UAE & 3 & \\
\hline Kazakhstan & 2 & & Kenya & 2 & \\
\hline
\end{tabular}

*compiled by the author $[5,33]$

- NextEra Energy (USA) is a leading clean energy company headquartered in Juno Beach, Florida. Having subsidiaries (Florida Power \& Light Company, NextEra Energy Resources, LLC), it is the largest tariff-regulated electricity company in the United States, the world's largest producer of renewable wind and solar energy, and a global leader in batteries, ranking first in the electricity and gas industry on Fortune's 2021 list of "The World's Most Respected Companies". NextEra Energy is included in the S\&P 100 index and is recognized by third parties for its efforts in the areas of sustainability, corporate responsibility, ethics, and diversity. NextEra Energy's GAAP net income for 3 months of 2021 was $\$ 1.50$ billion, demonstrating an increase of 4.8 times compared to $\$ 0.31$ billion in the previous year. The revenue decreased by $19.2 \%$ from $\$ 4.61$ billion to $\$ 3.73$ billion a year earlier. Over the past year, the stock rose from $\$ 60.49$ to $\$ 74.23$. Analysts predict further growth of quotations $[9,14]$.

The above examples indicate an increase in the scale of the activities of the largest foreign companies in the field of green energy. The growth in the share price shows the interest and confidence of investors in profitable investments, increasing the potential for sustainable development of the ecological and economic system and thereby providing opportunities to expand production and introduce equipment for saving electricity, resulting in improved ecology and lower consumer costs.

The development of green economy undoubtedly contributes to the improvement of the environment, but also plays an important role in the movement of the economy, increasing sustainability. The implementation of green energy projects leads to an increase in GDP, creation of new industries, higher employment, and an increase in the use of waste. The evidence is the following: increased volume of green energy production, changes in oil production technologies (abandoning gas burning and pumping it into the reservoir), waste disposal.

The green energy market in Russia is much smaller than in China, Europe, and America, but it shows growth over the past 20 years and its average annual growth is $3.2 \%$. The largest place in the green energy sector of Russia is occupied by solar energy, showing an increase of $37 \%$ per year, as well as wind energy, which has an average annual growth of $23.4 \%$ [27]. Figure 3 shows the dynamics of growth in the volume of renewable energy production in Russia. 

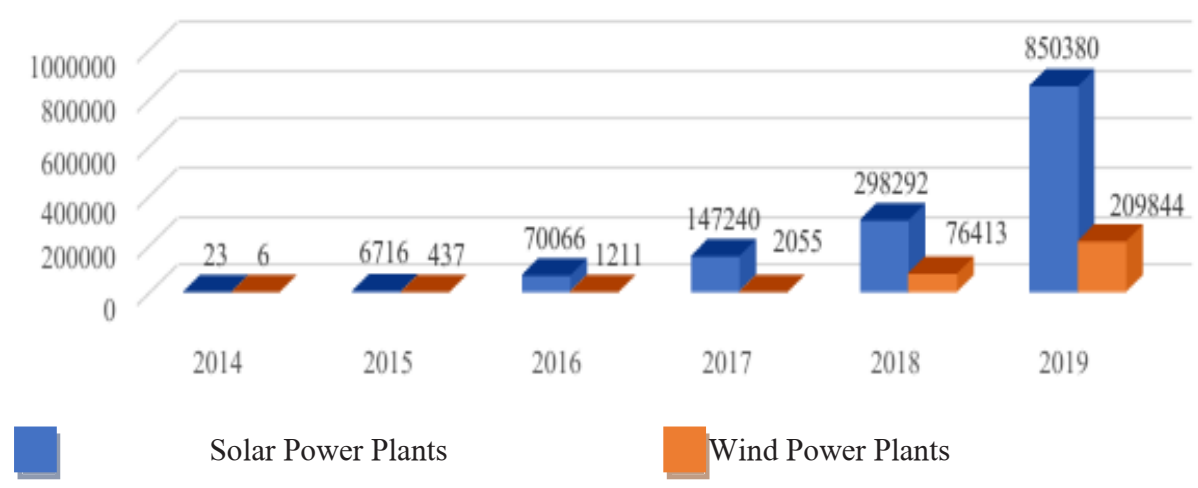

Fig. 3. Electricity generation using renewable energy sources in Russia, 2014-2019 (thousand kWh). (Compiled by the author according to [10,15]).

A distinctive feature of Russian practice in renewable energy production and generation is that the equity capital of enterprises in the structure of "green" investments is almost $90 \%$ (Table 4), while in most countries the main investor in green economy is the state, not the private sector.

Table 4. Structure of sources of financing of "green" investments in Russia, 2009-2019, \%*

\begin{tabular}{|l|c|c|c|c|c|c|c|}
\hline \multicolumn{1}{|c|}{ Sources of financing } & 2009 & 2011 & 2013 & 2015 & 2017 & 2019 & $\begin{array}{c}\text { Growth } \\
\text { rates, } \\
2009 / 201 \\
9\end{array}$ \\
\hline Total & 100 & 100 & 100 & 100 & 100 & 100 & \\
\hline Equity capital of enterprises & 75,47 & 72,02 & 78,73 & 88,04 & 86,50 & $\begin{array}{c}89,0 \\
5\end{array}$ & 117,9 \\
\hline Federal budget & 11,18 & 13,07 & 10,50 & 4,28 & 4,38 & 5,07 & 45,3 \\
\hline $\begin{array}{l}\text { Budgets of the constituent } \\
\text { entities of the Russian } \\
\text { Federation }\end{array}$ & 12,01 & 13,28 & 6,33 & 4,87 & 6,33 & 4,60 & 38,3 \\
\hline Other sources & 1,34 & 1,63 & 4,43 & 2,80 & 2,79 & 1,28 & 95,5 \\
\hline
\end{tabular}

*Calculated by the author [15]

We can give examples of projects of Russian oil and gas companies that, as part of their sustainable development, include renewable energy in their strategies, mainly using RES for their own energy needs. The share of renewable energy in Russia was about $0.4 \%$, or 1 GW (in the world-1449 GW). For instance, Rosneft's sustainable development strategy until 2022 includes the use of renewable sources at remote oil and gas production facilities. Tatneft has installed a hybrid wind-solar complex with a capacity of $7.8 \mathrm{~kW}$. In 2018 , Transneft launched two $250 \mathrm{~kW}$ solar power stations [22].

The key focus of Gazpromneft in the field of green economy is the use of financial resources to protect the atmosphere from the release of harmful substances. At the end of 2019, the company spent 14 billion rubles on capital investments in the renovation of environmental safety fixed assets. Recently, a solar power plant (SEP) has been put into operation on the territory of the Omsk refinery, which will provide the plant with additional generation, consequently leading to improved energy efficiency and environmental friendliness due to the use of unused in the technological process premises. Taking into account the insolation of Omsk, the estimated annual output of the station will be 1.2 million $\mathrm{kWh}$. This volume is equivalent to burning more than 1.8 thousand tons of coal, so 
more than 5 thousand tons of $\mathrm{CO} 2$ will not be emitted into the atmosphere by the coal-fired heating plants $[13,16]$.

Another example of increasing the share of renewable sources in the energy balance, the development of hydro, solar and wind generation is the Lukoil Group, which currently has a large portfolio of generating assets based on renewable energy, enabling us to prevent greenhouse gas emissions by more than 500 thousand tons of carbon dioxide per year. These include four hydroelectric power plants (HPPs) located in Russia with a total capacity of $291 \mathrm{MW}$, the Land Power wind farm in Romania with a capacity of $84 \mathrm{MW}$, and solar power plants in Volgograd, Romania and Bulgaria with a total capacity of over 20 MW. It is planned to launch the Krasnodar SES, which will allow Lukoil to generate about 3 million kWh of "clean" electricity per year, reducing annual emissions to 1.5 thousand tons of carbon dioxide. Two projects for the production of "green" hydrogen are under development - the project of the Tsimlyansk wind farm in the Rostov region with a capacity of $50 \mathrm{MW}$, as well as the wind farm in Romania - up to $120 \mathrm{MW}$. The total RES generation capacity of the Lukoil Group at the beginning of 2021 was 395 MW - 6\% of the total installed capacity, and the level of use of green technologies - 97.4\% [12, 25].

In general, the country has not yet fully implemented programs with participation of startups to work on the concept of sustainable development and reduction of the anthropogenic impact on the environment. A serious attention should be paid to these programs, since Russia is one of the major subjects of the world economy and therefore must follow global trends, and in this regard, one of the tasks is transition to eco-friendly production using green technologies, which will ensure competitive advantages in the international market. The timing of obtaining a positive economic effect remains a serious barrier to the development of the domestic green economy. At the initial stage, introduction of green technologies is quite expensive; the increase in company profits and GDP growth must be evaluated in the long term. Other barriers will be the complexity of transforming the bulky energy and transport infrastructure, as well as the lack of qualified personnel.

Currently, in the light of these problems, the government has begun to adapt foreign experience of "green" financial instruments in Russia. In 2019, the national project "Ecology" was started at the federal level, the total cost being more than 4 trillion rubles and the goals calculated until 2024. As part of its implementation, new plans and laws were adopted, the fundamentals of the state policy in the field of ecology were approved, which made it possible to attract external investments in the amount of 0.5 trillion rubles in 2019. [1]. For the environmental sphere, such systematic support is particularly important, since without a regulatory policy, the activities of economic entities are usually more short-term in nature than is required for the implementation of projects that have a long-term positive impact on the environmental situation.

In order to solve the problem of sustainable development, in August 2020 the first green project organized by the Skolkovo Fund with the support of key ministries of the country was launched. The Green Tech Startup Booster has been formed. It unites large industrial manufacturers of different industries in order to form the basis for the development of environmental startups. The participants of the Green Tech Startup Booster program are: SIBUR, NLMK, Helyx, Severstal, Tatneft, Gazpromneft, and Trubnaya Metallurgical Company. A number of participants are competitors, but their common understanding of the value of environmental cleanliness will lead to fruitful cooperation in this project. During the implementation of the program, there will be developed technologies to transfer the production facilities of the participants to a more environmentally friendly level. Startups will have an opportunity to quickly launch their developments with the involvement of private investment and government support. The involvement of foreign companies Total, EDF, and ENEL in the program will help to reach the international level $[3,7]$. 
The development of renewable energy in Russia is constrained by a number of circumstances. At the federal level, there are no goals for the development of renewable energy sources, and there are no correct beliefs about the feasibility and effectiveness of their use at the household level and the organization of production either. Many citizens of the country and officials do not have sufficient knowledge about the rational, efficient usage of solar and wind energy in residential buildings and factories. They do not understand that the production of solar energy can be cheaper than mass-used methods, either. [15]

The development of green energy in Russia has a number of advantages. First, there is no harm to the environment. The use of green energy significantly reduces the emission of greenhouse gases into the atmosphere. This means that the negative impact on climate change will be reduced, the environment will become cleaner and, as a result, the morbidity of the population, mortality and treatment costs will decrease. Secondly, it is inexhaustibility. The sources of energy are natural phenomena, e.g. the sun. They can provide uninterrupted, stable energy generation, especially in regions with limited energy resources, and can be used indefinitely. Thirdly, it is an increased efficiency of green energy production. The use of innovative technologies for the production of energy by the sun and the wind will reduce its cost and make this industry more attractive for investors. And lastly, we can solve social issues, namely create new jobs [2].

By the early 20s, there was not a single state that completely had switched to an ecofriendly level - in fact, the presence of individual elements of a particular system does not mean the existence of the system itself as such. Developing the elements of the green economy into a complete system in an abstract, separate state requires, first of all, a change in the tax system and the policy of state subsidies because private investments in this area of production are definitely not enough. It is usually assumed that this will mean both the introduction of taxes on non-ecological types of energy, and the abolition of subsidies for enterprises using them.

It should also be borne in mind that in the short term, the development of green economy can slow down the pace of development of the country's economy - and this is logical: it will be necessary to transfer literally all production to a new model, not only energy supply, but also the processing of materials and even the materials themselves will become different, based on environmental requirements. However, in the long term, green economy may be no worse than a modern one, since, a socio-ecological and economic model given, it is able to provide no less employment and income, and also offers social and environmental benefits. Summing up the current discussions in this sphere, the UN documents "The 2030 Agenda for Sustainable Development" and "The Paris Climate Agreement" proclaim an inextricable link between sustainable development and environmental conditions of human life, and therefore green economy. In fact, in the context of "sustainability", green economy itself is a vector of sustainable economic development due to its absolute compliance with the socio-economic and environmental system, provided that innovative technologies of the "eco-friendly" class are available for their intended purpose in relation to the environment. Indeed, when talking about green economy, we can't but mention sustainable development - there is, of course, a relationship between them, which, although not obvious, undoubtedly proves the possibility of achieving sustainable development in green economy.

\section{Conclusions}

Thus, if we consider "green investments" to be capital and other financial resources spent on reducing negative impact on the environment through financial instruments in order to achieve a balance between environment and economy, it can be assumed that acceleration 
of the green economy trend within the framework of sustainable development will not only change the nature of production, optimize it, increase energy efficiency, but also improve existing financial mechanisms and expand the range of investment instruments.

At the present stage, investments in green energy have a high degree of attractiveness as well as growth prospects. In recent years, there has been an increase in the production of green energy. The introduction of innovative technologies will reduce the cost of its production. Alternative sources will largely replace traditional sources in the next decade. Since green economy is a guideline of sustainable development of economy, the task of modern society is to ensure stable movement and growth of green economy. Investments are objectively the driving force of green economy, ensuring sustainable development of economy as a whole.

Investments in green economy will lead to improvement in the environmental situation, which will undoubtedly have a positive impact on the quality of life (social, physiological) and, as a result, on sustainable development of economy as a whole.

\section{References}

1. Passport of the national project "Ecology", http://www.consultant.ru/

2. A.Sh. Akulova, A.V. Shtramel', Innovative Science, 11, 87 (2020)

3. Renewable energy sources, https://csr2019.lukoil.ru/

4. A.A. Demchenko, A.V. Evchenko, G.A. Esenkova, Quality Management System: Diagnostic Analysis and Rationalization of Business Processes: A Study Guide (2020)

5. Dzhennet L. Sovin i dr. The state of renewable energy. Global report. Ren21, https://www.ren21.net

6. Green finance in Russia. Doklad-2020, https://infragreen.ru

7. Green energy is developing, http://nzs-zs.ru/

8. Investing in "green technology" - the future is now - 2021, https://ru.talkingofmoney.com/

9. Investments in green energy, https://mnogo-kreditov.ru/

10. S.I. Kodaneva, Russia and the modern world, 1, 46 (2020)

11. "Green" energy: a global fake or a bright future, https://newizv.ru/

12. LUKOIL shared plans for the development of renewable energy sources, https://nangs.org/

13. A solar power plant was put into operation at the Omsk refinery of Gazprom Neft, https://neftegaz.ru/

14. About NextEra Energo, https://investfuture.ru/

15. About the green finance market in 2020, https://infragreen.ru

16. Sustainability Report Gazprom, https://csr2020.gazprom-neft.ru/

17. Report on sustainable development "Lukoil", https://lukoil.ru/

18. V.V. Podgornyj, Economics and Management, 2(136), 49 (2017)

19. V.A. Plotnikov, M.R.A. Halil, Bulletin of the South-West State University. Series: Economics. Sociology. Management, 6(35), 57 (2019)

20. S.S. Polonik, E.V. Horobryh, A.A. Litvinchuk, Bulletin of Polotsk State University. Series d: economic and legal sciences, 13, 2 (2018)

21. "Green" financing in Russia: goals and contradictions of the modern market (RBC), https://trends.rbc.ru/ 
22. Russian Direct Investment Fund. Transactions, https://rdif.ru/

23. N.N. Semenova, O.I. Eremina, M.A. Skvorcova, Finance: theory and practice, 24(2), 39 (2020)

24. Sustainable Development Goals (UN) 2018, https://www.un.org/

25. Clear horizons. LUKOIL plans to increase capacity based on renewable energy sources, https://www.kommersant.ru/

26. D.B. Shcherbakov, Collection of articles V-ozh of the All-Russian scientific and practical conference dedicated to the 30th anniversary of the formation of the tax authorities of the Russian Federation, 508 (2020)

27. E.A.Borkova, M.R. Izusova, K.A.Gematdinova, Creative economy, 13(12), 2315 (2019)

28. Communication from the Commission. Action Plan: Financing Sustainable Growth, https://eur-lex.europa.eu/

29. J. Dlouhá and M. Pospíšilová, Journal of Cleaner Production, 172, 4314 (2018)

30. Fdi Renewable Investments of the Year 2019-the winners. Fdiintelligence, https://www.fdiintelligence.com

31. European Green Deal | European Commission, https://ec.europa.eu/

32. S.I. Mishulina, Sochi Journal of Economy, 2, 155 (2019)

33. Green foreign direct investment in developing countries. United Nations Environment Programme, http://web.unep.org/

34. H. Sun, Y. Wan, L. Zhang, Zh. Zhou, Journal of cleaner production, 235, 1315 (2019)

35. WCED Our Common Future: a Report from the United Nations World Commission on Environment and Development (1987), http://www.un-documents.net/

36. United Nations The Sustainable Development Goals Report (2019), http://www.un.org.lb/ 